\title{
Exploration on the reform of the science and engineering experiment teaching based on the combination with teaching and scientific research
}

Peng Song

Peng Song, "Exploration on the reform of the science and engineering experiment teaching based on the combination with teaching and scientific research," Proc. SPIE 10452, 14th Conference on Education and Training in Optics and Photonics: ETOP 2017, 1045258 (16 August 2017); doi: 10.1117/12.2269682

Event: 14th Conference on Education and Training in Optics and Photonics, ETOP 2017, 2017, Hangzhou, China 


\title{
Exploration on the reform of the science and engineering
}

\section{experiment teaching based on the combination with teaching}

\section{and scientific research}

\author{
Peng SONG*a \\ ${ }^{\text {a }}$ University of Jinan, School of physics and technology, Shandong, Jinan, 250022
}

\begin{abstract}
The existing problems of the experiment education in colleges and universities are analyzed. Take the science and engineering specialty as example, the idea of the combination with teaching and scientific research is discussed. The key problems are how the scientific research and scientific research achievements are used effectively in the experiment education, how to effectively use scientific research laboratories and scientific researchers. Then, a specialty experiment education system is established which is good for the teaching in accordance of all students' aptitude. The research in this paper can give the construction of the experiment teaching methods and the experiment system reform for the science and engineering specialties in colleges and universities.
\end{abstract}

Keywords: The combination with teaching and scientific research, the science and engineering specialty, reform of the experiment teaching

\section{INTRODUCTION}

According to "the opinions of the Ministry of education on further deepening the reform of undergraduate teaching and improving the teaching quality", practice credits are not less than $25 \%$ of the total credits for science and technology undergraduate specialty, and it is required to deepen the reform of education and teaching, strengthen the training of undergraduates ' quality and ability[1]. The experiment is the very important part of the practical teaching system for the science and engineering specialties in colleges and universities, which plays an irreplaceable role. The experiment is an effective method to develop undergraduate' intelligence, to cultivate undergraduate' practical ability, observation ability, scientific research ability, innovation ability, scientific attitude and rigorous style of work. The experiment will help to stimulate undergraduate' interest in learning, which is good for the theoretical teaching[2].

However, most of universities in China have paid more attention on research, and less on teaching, especially experiment teaching, which has seriously restricted the improvement of the quality of university teaching, and then makes the university education not meet the social needs[3]. The aim of experiment is to train students' experimental skills, practical application ability, scientific research ability and innovation ability according to their aptitude. It is an urgent problem to explore how to make full use of scientific research resources and integrate scientific research and its achievements into college experimental teaching.

\section{THE PROBLEMS OF EXPERIMENTAL TEACHING}

From the present teaching practice of most colleges and universities, there are still some problems in

*ss_songp@ujn.edu.cn

14th Conference on Education and Training in Optics and Photonics: ETOP 2017, edited by Xu Liu,

Xi-Cheng Zhang, Proc. of SPIE Vol. 10452, 1045258 - () 2017 ICO, IEEE, OSA, SPIE

CCC code: $0277-786 \mathrm{X} / 17 / \$ 18 \cdot$ doi: $10.1117 / 12.2269682$ 
the process of science and engineering experiment teaching, which reduce the effect of experimental teaching in the process of personnel training, and greatly limit the implementation of the professional training objectives.

\subsection{Bad combination between experimental teaching and scientific research}

There is a wrong opinion that scientific research practice should be paid more attention and the teaching less attention. This wrong opinion leads to the present status that most of the funds are put on the scientific research, which doesn't serve the education. The combination between experimental teaching and scientific research is bad, which is the reason to the bad effect of scientific feedback teaching.

\subsection{The experimental teaching instruments cannot meet the teaching needs}

The teaching instruments for science and engineering specialties are relatively expensive. For schools or specialty with limited funding for teaching, the experimental instruments are usually severely inadequate. Thus single instrument has to be arranged to more than one student at the same time. Meanwhile, the total number of the experiments usually cannot meet the teaching needs in the process of teaching and training.

\subsection{The old experimental teaching equipment can not represent the frontier of professional development}

The lack of funds for laboratory equipment usually results in a long cycle of equipment renewal. Teachers teach advanced theories and techniques, new equipment and new methods in theoretical classroom teaching. However, students are often exposed to outdated or damaged experimental equipment, which cause inevitable contradiction between the backwardness of experimental means and the rapid development of science and technology. The contradiction influences the transition between the university education and social practice for students, which reduces the adaptability and competitiveness of students' postgraduate entrance examination or work.

\subsection{The experimental teaching mode cannot meet the needs of students' individual development}

At present, most of the colleges and universities are face with the lack of experimental equipment and laboratory. So students of all professional direction do the same experiments at the given time, which don't consider the needs of different professions direction. The traditional teaching mode is unable to provide the contents of experimental teaching and training according to their own conditions of interest and the future direction of development, and meet the education concept of treating pupils as individuals. Thus, the traditional unified teaching mode cannot meet the requirements of diversification of talent training.

\section{THOUGHT AND CONTENT OF REFORM}

The core contents of the experimental teaching reform is how to effectively use all kinds of teaching and scientific equipments, take full advantages of high level scientific research teachers, adopt suitable management of teaching arrangement, and bring scientific research achievements and scientific research training into undergraduate teaching process. Its purpose is to train students' basic quality of scientific research, thinking and consciousness, then improve the competition ability of graduate school exams and employment. Specific research content is divided into the following four parts:

3.1 Setting up a specialty experiment teaching system with organic combination of scientific research and teaching

The students should participate in the scientific research activities and technological innovation competition, which can be combined with the specialized experimental teaching organically. We can 
set up a specialized experimental teaching system consisting of specialized laboratories, scientific research laboratories and students' second classrooms. In the process of construction and reform of experimental teaching, we should adhere to professional construction and laboratory construction combination, theoretical teaching and practical teaching combination, experimental teaching and scientific research combination.

\subsection{Setting up a professional experimental teaching team of integration of scientific research and teaching, full of earnest and innovation}

We can fully mobilize and coordinate research teachers with high academic qualifications related to the photoelectric information science and engineering, to combine with the original professional experimental teaching team, which can achieve team effectiveness of 'scientific research + teaching', i.e., ' $1+1>2$ '. Teachers should devote more time and energy to integrate their research projects, scientific and technological achievements into undergraduate experimental teaching, and guide students to engage in higher levels of scientific experimental research. We should construct learning and teaching innovative teams, make innovation on the teaching concept, teaching system, teaching methods and other aspects to achieve a substantive breakthrough in teaching reform.

\subsection{Establishing professional experimental teaching method of individualized teaching and personality development}

We should give full play to the advantages and features of scientific research laboratory equipment, and establish multi-style professional experimental items of compulsory experiment project, elective experimental projects, research projects and innovation experiment project. According to the students' learning situation, hobbies and development requirements, they are chosen as the experimental items for the class hour. In the experimental teaching methods, the students should realize the transforms of passive into active acceptation, simple verification into synthesis design, and imitation operation into the innovation practice.

\subsection{Forming a diversified and structured assessment mechanism of professional experiment with various forms}

Students select different types of professional experimental items according to their individual characteristics, then the specific indicators and forms of evaluation are adopted for different types of experimental projects, according to cultivating student different abilities of the project itself, which is charged by the experimental project guide teacher, according to the evaluation index for assessment. The above practices will set up a diversified and structured assessment mechanism of professional experiment with various forms.

\section{CONCLUSION}

Some suggestions and ideas for the development and reform of the experimental teaching of science and engineering specialty are put forward in this paper. Firstly, the construction of experimental teaching should be paid more attention, which can make the students better get the basic experimental and practical ability, cultivate students' innovative consciousness and ability, and then improve the employment competitiveness of students. Secondly, the experimental teaching construction and innovation reform can promote the reform of the specialized curriculum system.

\section{REFERENCES}

[1] ZHENG Xiaodong, LIU Xiangdong, "Improvements in the laboratory education program of optical engineering," Optical Technique33 (S1) ,280-281(2007).

[2] LIAO Qingmin, QIN Gangnian, LI Mianyuan, "Integrating scientific research into 
experimental teaching to improve the innovation and comprehensive quality of students," Research and Exploration in Laboratory28 (3) , 15-18(2009).

[3] WEI Hua , ZENG Dongmei , QIN Gangnian, "Combining experimental teaching with scientific research to develop students' innovativeability," Experimental Technology and Managemen25 (5),31-34(2008). 